\title{
A Late Quaternary Stratigraphic Marker in the Central Basin of Baffin Bay*
}

\author{
DAVID J.W. PIPER
}

Departments of Geology and Oceanography, Dalhousie University, Halifax, Nova Scotia

In summer 1971 - an $8-\mathrm{m}$ long, $6.4-\mathrm{cm}$ (2.5 ins) diameter piston core was collected on Bedford Institute cruise 71-032 from the central basin of Baffin Bay, at $68^{\circ} 55.6^{\prime} \mathrm{N}$, $62^{\circ} 36.4^{\prime} \mathrm{W}$, in about $1000 \mathrm{~m}$ of water. Part of the core was subsequently lost when it fell to the deck during a storm, and shattered into many pieces. About $450 \mathrm{~cm}$ of the core were salvaged. This core is believed to be the first core longer than $3 \mathrm{~m}$ to be collected from Baffin Bay.

The upper part of the core (Fig. 1) consists of olive-grey mud with large amounts of sand and coarser detritus, presumably icerafted. Most of the clasts are crystalline rocks, but around $15 \%$ are carbonates. About $18 \%$ of the fine fraction is carbonate. Interbedded are occasional graded beds of well sorted sand, a few centimetres thick, believed to be turbidites. Other beds of mud, with no gravel, and virtually no sand, are also believed to be turbidites. Such beds frequently overlie graded sands, but are also found on their own. About $40 \%$ of the upper part of the core appears to be ice-rafted material.

The lower part of the core consists of sand- and gravel-free olive-grey muds, probably turbidites, interbedded with dark yellowish brown muddy carbonate ooze, with a carbonate content of 40 to $50 \%$. The carbonate beds are tens of centimetres thick. They contain dispersed sands and pebbles, which are presumably ice-rafted. One pebble completely filled the core liner. $30 \%$ of the pebbles and sands are of carbonate, whereas about $60 \%$ of the silt and clay-size sediment is carbonate. Smear slides show that the finer carbonate is mostly in the form of anhedral grains 1 to 15 microns in size. One carbonate bed, $27 \mathrm{~cm}$ thick, contains no sand or coarser material. Near the base are laminae of terrigenous silt. There is a concentration of coarse sand and granules at the base of the bed, where it rests on mud. This is in marked contrast to the usual dispersed sand and pebbles, and suggests current action in depositing this bed.

Biogenic material is extremely rare throughout the core. A few sponge spicules and exceptionally a diatom are found in samples. No trends in occurrence of biogenic material could be established through the core.

Marlowe (1966, 1968) from an examination of a number of 1 to $3-\mathrm{m}$ long cores, found carbonate gravel and sand to be common in cores from the western side of Baffin Bay. He suggested that this material was introduced by icebergs from Lancaster Sound. The region with abundant carbonate detritus appeared to be more extensive at lower levels in the cores. However, he did not record any distinctive

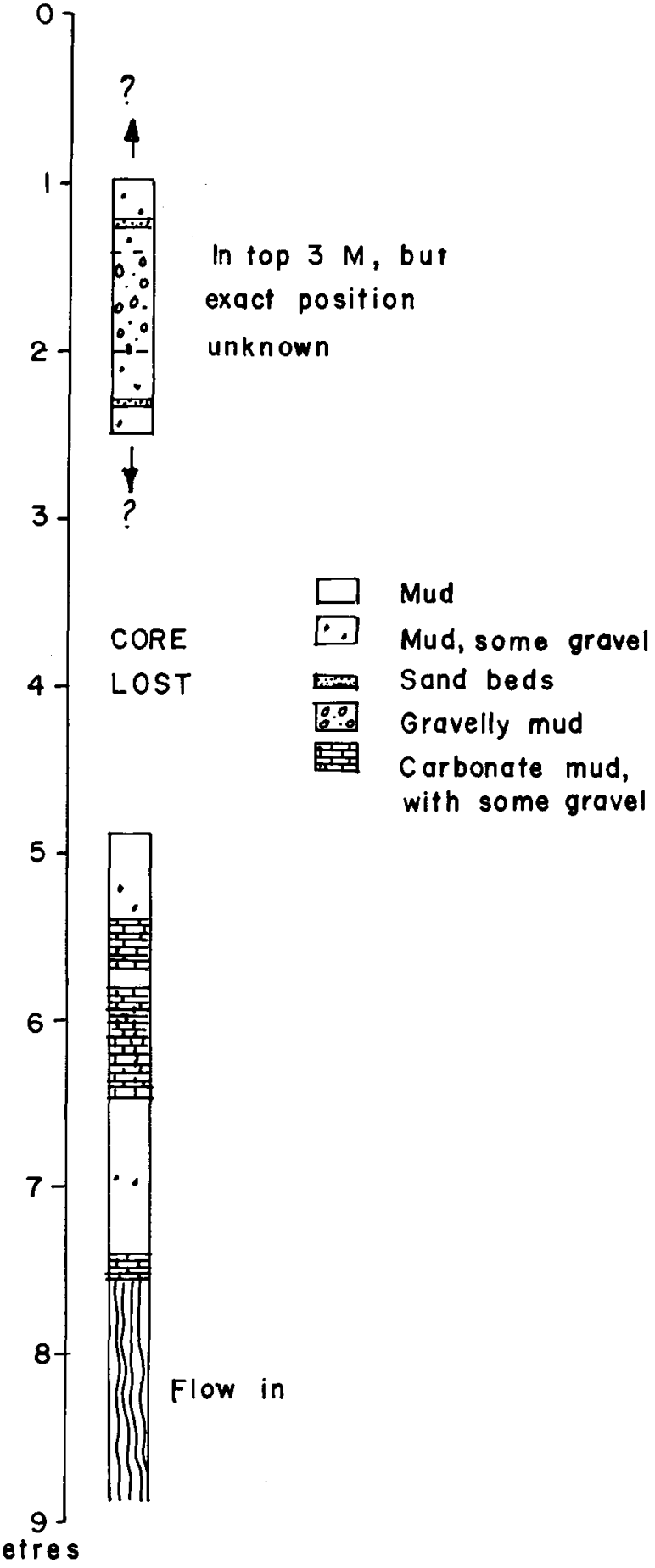

Fig. 1. Principle lithologies in Core 71-032-1 from the $1000 \mathrm{~m}$ deep central basin of Baffin Bay. 
carbonate muds of the type found in the core described here. Grant (1971) found limestone to be the dominant lithology in surficial gravels from the northwestern part of the Bay, around Lancaster Sound.

The proportion of carbonate clasts in the upper part of the core described here is similar to that found by Marlowe in his cores from western Baffin Bay; and his explanation for their occurrence seems satisfactory.

Two prominent changes in the core need to be explained. One is the overall increase in carbonate detritus in the lower part of the core; the other is the increase in the proportion of fine to coarse-grained carbonate material.

A marked increase in the overall abundance of carbonate detritus, as is found in the lower part of the core, is most simply the result of more extensive glaciation and calving in the areas north and west of Baffin Bay. Marlowe's (1966) suggestion of changing patterns of surface circulation appears unnecessary. With present-day circulation patterns, limestone detritus would reach all those parts of the Bay in which it is found in the past (see Marlowe's Fig. 4). At what stage of glacial advance limestone detritus would become dominant is not obvious.

One explanation for the higher proportion of fine-grained carbonate is that the grain size distribution of sediment transported by icebergs from Lancaster Sound has changed with time. Piper and Brisco (1974) found that.grain size distribution of ice-rafted debris in the Ross Sea reflects the intensity of ablation prior to calving. The abundant fine-grained carbonate may indicate colder conditions in Lancaster Sound.

Alternatively, the carbonate mud may reflect a source of carbonate detritus from the adjacent land. At the present time, much of the mud that is accumulating in the deep basin of Baffin Bay is hemipelagic or turbidite, derived from the shelf off Baffin Island. The carbonate mud might reflect a time when the Laurentide ice sheet flowed from northern Hudson Bay directly across Baffin Island (Ives and Andrews, 1963; Andrews and Barnett, 1972), which could have brought carbonate detritus directly to the area.

Some estimates on the order of magnitude can be made for the rate of sedimentation of ice-rafted material in Baffin Bay, and hence the age of the lower sarbonate-rich part of the core. Icebergs are abundant in Baffin Bay, and relatively few escape into the Labrador Sea. A high rate of ice-rafted sedimentation might therefore be expected. The highest known rate of ice-rafted sedimentation for an open sea is $40 \mathrm{~m}$ per million years for the Miocene of the Ross Sea (Barrett, 1974). At this time, the Ross Sea was probably very similar to Baffin Bay, with icebergs calving off valley glaciers rather than ice shelves, and very few bergs escaping from the sea.
About $40 \%$ of the preserved part of the core described here appears of ice-rafted origin. This is equivalent to a total thickness of about $3 \mathrm{~m}$. Assuming a rate of ice-rafted sedimentation similar to the Miocene Ross Sea, the age of the base of the core would be 70,000 $\mathrm{BP}$; a rate five times greater than this puts the base of the base of the core at about $13,000 \mathrm{BP}$.

The core does not appear to penetrate interglacial sediments. Carbonate detritus is dominant throughout the lower part of the core. It thus records only Wisconsin and Holocene sedimentation. The disappearance of abundant carbonate detritus must represent a certain phase of deglaciation, and is therefore scarcely likely to be earlier than 14,000 BP. This date would imply a rate of ice-rafted sedimentation of about $50 \mathrm{~m}$ per million years. This figure must be regarded as a minimum, with a probable rate being perhaps twice this. The overall rate of sedimentation, taking into account the action of turbidity currents, is about three times higher than the ice-rafting rate, or around $300 \mathrm{~m}$ per million years.

\section{References Cited}

ANDREWS, J.T. and BARNETT, D.M., 1972, Analysis of strandline tilt directions in relation to ice centres and post-glacial crustal deformation, Laurentide Ice sheet. Geografiska Annaler, 54 A, p. 1-ll.

BARRETT, P.J., 1974, Textural characteristics of Cenozoic pre-glacial and glacial sediments at Site 270, Ross Sea, Antarctica. In Hayes, D.E., Frakes, L.A. et al., Initial Reports of the Deep Sea Drilling Project, vol. 28.

GRANT, A.C., 1971, Distributional trends in the Recent marine sediments of northern Baffin Bay. Maritime Sediments, 7, p. 41-63.

IVES, J.D. and ANDREWS, J.T., 1963, Studies in the physical geography of north central Baffin Island, N.W.T. Geog. Bull., 19, p. $5-48$.

MARLOWE, J.I., 1966, Mineralogy as an indicator of long-term current fluctuations in Baffin Bay. Can. J. Earth Sci., 3, p. 191201.

, 1968, Unconsolidated marine sediments in Baffin Bay. Jour. Sedim. Petrol., $38, p$. 2065-1078.

PIPER, D.J.W. and BRISCO, C.D., 1974, Deep water continental margin sedimentation, D.S.D.P. Leg 28, Antarctica. In Hayes, D.E. 